\title{
Critical Points Against an Australasian Therapeutic Recreation Association: Towards Community Leisure through Enabling Justice
}

\author{
Annals of Leisure Research, 2004, 7(2), pp.95-103
}

\author{
Dr Simone Fullagar \\ Senior Lecturer \\ Department of Tourism, Leisure, Hotel and Sport Management \\ Mt Gravatt Campus \\ Griffith University \\ Brisbane 4111 Queensland
}

AUSTRALIA

Ph: 61738755676 Fx: 61738755661 Email: s.fullagar@griffith.edu.au

Dr Simon Darcy

Senior Lecturer

School of Leisure, Sport and Tourism

Faculty of Business

University of Technology, Sydney

PO Box 222

Lindfield NSW 2070

AUSTRALIA

Ph: 612 9514-5100 Fax: 612 9514-5195 Email: $\quad$ Simon.Darcy@uts.edu.au

\begin{abstract}
The purpose of this paper is to articulate arguments against the establishment of a therapeutic recreation association in Australasia. The authors believe that this is an important debate as the outcomes will place people with disabilities in very different locations within leisure discourse. It is argued that the establishment of a therapeutic recreation association will reinforce medicalised conceptions of disability that disempower individual freedom for professional control. This course of action does not recognise the contemporary influences of social approaches to disability that seek to provide an enabling environment to empower people with disabilities to forge their own leisure identities. Further, the history and development of therapeutic recreation has cultural contexts that require examination from an Australasian perspective. The arguments presented are informed by contemporary ideas within leisure theory, disability studies, human rights approaches to marginalised groups and the broader citizenship literature.
\end{abstract}




\section{Introduction}

This paper articulates arguments against the establishment of a therapeutic recreation association in Australasia. In doing so, the authors recognise that if professionals wish to establish such an association then they will do so whether or not people voice concerns about such an association. However, the idea of professionalising recreation provision around therapeutic paradigms requires critical discussion by organisations like ANZALS and in the academies where leisure education occurs. The arguments presented are not just the opinions of the authors but are drawn from contemporary ideas within leisure theory, disability studies, human rights approaches to marginalised groups and the broader citizenship literature.

\section{Discussion}

The defining feature of disability theory has been its focus on the social exclusion and oppression of disabled people. The barriers are embedded in policies and practices based on the individualistic, medicalised approach to disability (Barnes, Mercer and Shakespeare, 2002:168)

This comment by disability theorists clearly articulates a social understanding of 'disability' that is becoming increasingly influential in current thinking within disability studies. In short, disability involves a complex set of social relationships imposed on top of a person's impairment due to the way society is organised. However, disability studies is only starting to make an impact within leisure studies and related professional domains. Understanding how our society works to create disabling conditions for individuals with different impairments or lifestyle needs, requires a thorough analysis of the material, cultural and spatial organisation of leisure. From this perspective, leisure is understood as a right or social need that all individuals are entitled to as citizens within a democratic system that recognises different identities and ways of living.

These rights were enshrined in the United Nations (1948) Universal Declaration of Human Rights. However, the rights of people with disabilities were not specifically recognised until the Declaration on the Rights of Disabled Persons (United Nations, 1975). The UN followed this by declaring 1981 as the International Year of Disabled Persons (IYDP) (United Nations, 1976). The decade of the 1980s was a watershed in western disability history where many of the assumptions of the medical model were 
challenged. In 1993, the UN General Assembly passed a resolution, The Standard Rules on the Equalisation of Opportunities for Persons with Disabilities (United Nations, 1993), which adopted a social approach to disability, calling upon governments to provide for the equalisation of opportunities for people with disabilities in all aspects of their lives. The resolution identified recreation and tourism as target areas.

Central to the UN human rights declarations was the recognition that people with disabilities should enjoy the rights of citizenship of its signatory nations. The UN provides the foundation of citizenship through the international framework of human rights. Yet, as Hutchison (1997:2) states, recognising human rights is only part of establishing citizenship for people with disabilities. Each country operationalises these rights under its own legislative and policy frameworks. These frameworks require governments to resource and regulate their implementation to enable people with disabilities to access citizenship that the frameworks are designed to achieve. Citizenship has become a rallying point for many disability groups in Australasia and overseas. For example, as the Physical Disability Council of NSW (1999) states, this includes the right to access to the built environment, aids and equipment, attendant care, transport, employment/vocational training, cost of disability income support, education, housing, health and leisure. The reason that people with impairments experience restricted access to these key aspects of citizenship can be understood in relation to the disabling nature of social environments that are based upon nondisabled norms and attitudes that exclude difference (Barnes, 1996; Oliver, 1990).

This combination of citizens with disabilities calling for greater recognition of the social nature of disablement and the introduction of national human rights legislation has raised a key issue for leisure services and professionals. That is, the need to review the fundamental nondisabled assumptions and power relations that govern how people with disabilities are constructed and positioned as objects of professional 'expertise', rather than as subjects of their own lives and decision making processes. People with disabilities not only have a growing awareness that they should be controlling their own lives but have legal mechanisms through which to enact their rights and forge their own leisure identities. As a review of the Australian Disability Discrimination Act, 1992 complaint cases and Federal Court actions demonstrates, 
people with disabilities are discriminated against by leisure service providers on a daily basis and are taking action to redress cases of direct and indirect discrimination (Darcy, 2002b). These cases can be as blatant as refusing a blind person admission to a venue because they have a guide dog assisting them, or as prohibiting as advertising sports training programs for people with spinal cord injury but not providing adequate toilet and changing rooms to accommodate their involvement (see Human Rights and Equal Opportunity Commission, 2004)

There are stark differences between the social and medical/therapeutic models that inform professional knowledge, practices and discourses related to disability and leisure. One of the major implications for leisure professionals working within therapeutic recreation relates to the all-pervasive influence of the medical model that defines disability as a problem or deficit of individual impairment. Medical discourses have historically failed to engage with the socio-political nature of disability and, hence, they can work today to undermine the citizenship gains that people with disabilities have made by failing to identify the power relations that shape disablement, perpetuate discrimination and limit leisure opportunities. For example, a therapeutic recreation rehabilitation specialist might develop functional adaptations that enhance the immediate quality of an individual's leisure life. However, when that person is returned to their 'community' there is an expectation that they will be physically as 'normalised' as possible within their impairment deficit and they must fit into their social surroundings. Yet, the basis of their citizenship (e.g., access to personal care, housing, transport, education, employment, retail, recreation) in the community is highly politicised with respect to funding responsibilities taken up by the state or assigned to the individual and the vagaries of market forces.

The rehabilitation environment reflects the broader political view of disability and citizenship. Over the 1990s across most Western nations, disability policy and, hence, rehabilitation has been heavily influenced by neoliberalism (Handley, 2001; Thornton, 2000). Rehabilitation, broader government and disability policies are structured to produce functional neoliberal citizens who could become self-sufficient through employment, which in turn legitimated their leisure lives. This leads to a dichotomy where employment outcomes and 'welfare dependence' are the dominant policy concerns for program areas. Leisure programs become the focus of government 
cutbacks as they are viewed as a luxury for those who have employment where the unemployed should spend their time to constructively gained employment whether that is possible or not. Recently in Australia, this has occurred at Commonwealth and State level with funding reductions for people with intellectual disability who are unable to enact the type of autonomous citizenship that the government expects (DADHC 2004). Of course, if they fail this neo-liberal test of citizenship then their lives are categorised solely in terms of social dependence where they must legitimise their existence as 'deserving' welfare recipients. Yet, it is this same bureaucracy, which ignores the social inequities surrounding disability access and does not provide enough support for people to enact their citizenship in the same way as the nondisabled. Once excluded from the legitimatised domain of employment-based citizenship, the same bureaucracy limits people with disabilities' quality of life through practices of reduction, omission and exclusion of leisure opportunity.

The therapeutic recreation approach has emerged out of a specific North American culture, health care and medical insurance system, and professionalised history that does not directly translate to an Australasian context either professionally or academically. Aitchison has recently identified these tensions within leisure and disability research,

...much of the North American research on disability and leisure is underpinned by a medical model of disability that offers few possibilities for disrupting the paternalistic discourse of therapeutic recreation. Whilst such research has undoubtedly made a positive contribution to physiotherapy and recreation therapy, its contribution to critical social science has been limited as a result of its denial of the social construction of disability and disabled people (Aitchison, 2003: 964).

An Australasian therapeutic recreation association would enhance the professional identities of primarily nondisabled 'experts' thus perpetuating disabling discourses that focus upon individual impairment at the expense of more critical engagement in social and political issues of inclusion, universal design and leisure identity empowerment processes. The focus of therapeutic recreation programs and services works to position people with disabilities as dependent objects of intervention, surveillance and regulation, rather than as being able to exercise power in their own lives (Foucault, 1980). While therapeutic recreation is informed by 'helpful intentions' within the establishment of therapist/patient-client relations there is an 
implicit power relation that is unacknowledged (and thus is difficult for people with disabilities to challenge). The professionalisation of therapeutic recreation in Australia would work to solidify the power relations that privilege 'expert' opinion, rather than the voices of people with disabilities. The centrality of the medical model to therapeutic recreation works to reinforce the power relations that should be continually challenged through the establishment of community networks and disability representation. The question of representation and power remains - how many people with a disability are actually employed in such roles as experts themselves?

This tension emerges around the issue of how leisure itself is conceptualised as either a therapeutic 'means' to a measurable end (better functioning, wellbeing, improved health outcomes) or as an 'end' in itself. While there are many positive benefits associated with leisure experiences, when leisure is discursively constructed as 'therapeutic' it becomes translated as a means to professional and bureaucratic ends. The very notion of leisure as negotiated freedom is reinvented by professionals as a therapeutic, self-actualising domain somehow separate from collective and political concerns (Rose, 1999). In this sense, a person's agency is divorced from the social processes and structures that contextualise the meaning of 'functional improvement' as the individual is separated from the social conditions that disabled or enable citizenship. Therapeutic recreation is instead a vehicle for improving the 'functional' status of individuals and thus is driven by an implicit health moralism that promotes 'normalised' and sanitised leisure activities and identities. Conceptually, this leads to a double standard as forms of 'leisure on the margins of conventional morality' are not presented as an option for 'patients-clients' but are available to staff and other citizens who have a right to freely choose the leisure of their desires without professional regulation, intervention or omission (Lynch and Veal, 2001).

Therapeutic recreation professionals in health care settings are governed by medical and policy discourses that are embedded within the broader economic and political organisation of funding and 'outcomes' frameworks. Hoss and Stumbo comment on the current pressures in the American system, 
Virtually every aspect of today's health care is driven by managed-care concepts...Understanding the process and flow of managed care is mandatory to defining the role and responsibilities of the therapeutic recreation profession (Hoss and Stumbo, 2001:304).

This outcome focus regulates the nature of programs and political agendas within the American therapeutic recreation profession and limits the freedom that professionals have to question and critique the system that funds them. This health system is governed by discourses of profit maximisation, economic rationalism and managing insurance cost/risks (where issues of pre-existing and genetic conditions raise a host of issues about insurance discrimination). Australasian health care systems are very different and leisure specialists tend to work largely within publicly funded systems and interdisciplinary teams (governed by other allied health and medical staff). However, with the increasingly conservative neoliberal climate there are growing pressures upon the health, aged care and disability sectors with service standards and regulations that link quality service provision to funding arrangements.

While such standards may work in one sense to promote leisure and quality of life, protect people from institutionalised abuse and facilitate an active role for service users, they exercise a powerful influence over the way leisure and disability are governed. This is manifested in three ways within the present Australian system. First, the focus on employment as the legitimate area of disability citizenship funded by the Commonwealth government. Second, the funding of leisure programs through service providers as the gatekeepers of leisure experiences for people with disabilities, rather than people with disabilities having significant influence over the services and programs provided. Third, and while not the focus of this paper, the citizenship of people with disabilities and people of other marginalities, is significantly disempowered under neoliberalist agendas through an attack on the implementation of human rights frameworks in Australia (Handley, 2001; Thornton, 2000)

In Australia, there are currently a number of professional and academic leisure and recreation bodies engaged in the process of professionalising their identities with respect to different domains (Diversional Therapy in aged care; Parks and Leisure Australia special interest group for Recreation Specialists in Disability/Specific Populations; Australian and New Zealand Association for Leisure Studies 
(ANZALS), NICAN, World Leisure committee on leisure and special populations). As theses bodies have very different philosophical and practice contexts it does not make a lot of sense to create a therapeutic recreation association to either combine current approaches (a very political move!) or create a competing body. There is, however, plenty of room to open up further dialogue about the nature and future of leisure specialists working with diversity groups in creating better processes of debate and representation 'of' people with disabilities themselves. This involves processes of empowerment where people with disabilities are invited into the academies, given control over their leisure choices and the form of their engagement.

There is also another way of thinking about how leisure professionals can seek to create enabling environments. Rather than consolidating professional expertise, leisure professionals can forge external alliances with the disability rights movement, other identity/social movements (e.g., queer, environment, women, indigenous, refugee, older persons), and professional bodies that work from medical models (Occupational Therapists, Physiotherapy, Diversional Therapy, Medical Practitioners). This engagement with other professional players pushes the boundaries of their expertise, rather than consolidating the expertise of leisure professionals around the highly selective and singular identity of therapeutic recreation. In this way, we can push for more enabling policies, programs and ways of working across and within specific discipline areas.

This also raises the issue of how we educate the leisure professional of the future to engage with issues of difference and diversity in critical and creative ways. We need affirmative policies that encourage more students with disabilities to complete our courses and support them to take up leadership roles. Creating more inclusive professional practices also involves teaching leisure students to become reflexive practitioners (Taylor and White, 2000) and not simply experts 'about' disability. Reflexivity is a notion that moves beyond the practice of simply reflecting upon one's professional actions to embrace the post-structuralist concept of power as an everpresent force that regulates the identities, freedom and conduct of both professionals and people with disabilities (Rose, 1999; Whitson, 1999). It is important that leisure students develop a professional ethos of 'critical empathy' so that they may work to 'build alliances' between people with and without disabilities across all kinds of 
social groups and differences (Kivel and Kivel, 2000). This is a process of politicisation whereby the leisure professional is awakened to their own power to 'engage with' others whose identities are rendered invisible by nondisabled, heterosexist and white discourses, or made visible only as objects of professional intervention (clients, patients, service users). We wrote this article through our own experiences of 'difference' related to disability, gender and sexual identity, that all work to shape how we begin to view the social forces shaping leisure opportunities and the kind of society we live in.

\section{Conclusion}

In contrast to the highly individualised discourse of therapeutic intervention, leisure practitioners need to work through the principle of 'enabling justice' (Gleeson, 1999) to understand and challenge the disabling effects of social discourses and institutional structures on leisure opportunities. From this perspective, leisure professionals can work to promote the citizenship of people with disabilities and not simply 'provide' a service. This means moving beyond the individual/social opposition that informs much professional thinking and towards a better understanding of the interdependent nature of individuals and society - where difference and inclusion are constantly negotiated. Leisure is an important mediating experience through which we construct and circulate stories about our citizenship, identities and differences as social beings, thus opening up notions of inclusivity and questioning notions of normalcy and rights of citizenship (Darcy, 2002a; Fullagar and Owler, 1998). According to Gleeson (1999: 148):

Enabling justice requires the production of spaces and places which guarantee the capacity of all to participate in social life in meaningful ways, such that each individual's material and non-material needs are satisfied (e.g., inclusion, affectivity, liberty) (Gleeson, 1999:148).

Gleeson's comment challenges all of us as leisure academics and professionals to consider how we build alliances to counter the effects of disability oppression and move towards a society premised on an enabling citizenship, rather than a dominant, exclusionary notion of normality. 


\section{References}

Aitchison, C. (2003) From Leisure and Disability to Disability Leisure: Developing Data, Definitions and Discourses. Disability \& Society, 18(7), 955-969.

Barnes, C. (1996) Theories of Disability and the Origins of the Oppression of Disabled People in Western Society. In L. Barnes (ed) Disability and Society: Emerging Issues and Insights. New York, Longman.

Barnes, C., Mercer, G., and Shakespeare, T. (2002) Exploring Disability: A Sociological Introduction. Malden, Mass, Polity Press.

Darcy, S. (2002a) Marginalised Participation: Physical Disability, High Support Needs and Tourism. Journal of Hospitality and Tourism Management, 9(1), $61-72$.

Darcy, S. (2002b) People with Disabilities and Tourism in Australia: A Human Rights Analysis. Paper presented at the Tourism and Well Being - 2nd Tourism Industry and Education Symposium. Jyvaskyla, Finland, 137-166

Department of Ageing, Disability and Home Care (DADHC) (2004) Adult, Training, Learning and Support (ATLAS) Reforms. Retrieved 1 November 2004 from http://www.dadhc.nsw.gov.au/

Foucault, M. (1980) Power/Knowledge. New York, Harvester Wheatsheaf.

Fullagar, S., and Owler, K. (1998) Narratives of Leisure - Recreating the Self. Disability \& Society, 13(3), 441-450.

Gleeson, B. (1999) Geographies of Disability. London, Routledge.

Handley, P. (2001) 'Caught between a Rock and a Hard Place': Anti-Discrimination Legislation in the Liberal State and the Fate of the Australian Disability Discrimination Act. Australian Journal of Political Science, 36(3), 515-528.

Hoss, M., and Stumbo, N. (2001) Perspective: There are No Simple Conversations in Health Care. In N. Stumbo (ed) Professional Issues in Therapeutic Recreation: On Competence and Outcomes, Champaign, Ill, Sagamore, 303314.

Human Rights and Equal Opportunity Commission (2004) Disability Rights Website Complaint Cases. Retrieved 23 October 2004 from www.hreoc.gov.au/

Hutchison, P. (1997) Citizenship - Setting the Scene (Keynote Address). Paper presented at the Citizenship...beyond Disability Conference, Brisbane, 3-17

Kivel, P., and Kivel, B. (2000) Beyond Cultural Competence: Building Alliances and Sharing Power in Recreational Programs. In M. Allison and I. Schneider (eds) Diversity and the Recreation Profession: Organisational Perspectives. State College, PA, Venture, 262-277.

Lynch, R., and Veal, A. J. (2001) Australian Leisure (2nd ed). Melbourne, Longman Cheshire.

Oliver, M. (1990) The Politics of Disablement. Basingstoke, Houndmills, Macmillan. Physical Disability Council of NSW (1999) Position Papers '99 - Citizenship and Physical Disability. Sydney, Physical Disability Council of NSW.

Rose, N. (1999) The Powers of Freedom: Reframing Political Thought. Cambridge, Cambridge University Press.

Taylor, C., and White, S. (2000) Practising Reflexivity in Health and Welfare: Making Knowledge. Buckingham, Open University Press.

Thornton, M. (2000) Neo-Liberalism, Discrimination and the Politics of Resentment. In M. Jones and L. Marks (eds) Explorations on Law and Disability in Australia. Leichhardt, NSW, Federation Press, 8-27. 
United Nations. (1948) Universal Declaration of Human Rights. Geneva. www.un.org/Overview/rights.html: United Nations.

United Nations. (1975) Declaration on the Rights of Disabled Persons. Geneva. www.unhchr.ch/html/menu3/b/72.htm: United Nations.

United Nations. (1976) The International Year of Disabled Persons 1981 (General Assembly Resolution 31/123), Geneva.

www.un.org/esa/socdev/enable/disiydp.htm: United Nations.

United Nations. (1993) Standard Rules on the Equalization of Opportunities for Persons with Disabilities (General Assembly Resolution 48/96). Geneva, United Nations.

Whitson, D. (1999) Of Managers and Therapists: A Deconstruction of Leisure Discourses. In G. Fain (ed) Leisure and Ethics: Reflections on the Philosophy of Leisure. Virginia, American Alliance for Health, Physical Education, Recreation and Dance, 161-170. 